\title{
Profitability of Small and Medium Enterprises in Albania (Focusing in the City of Tirana) \\ Bitila Shosha, PhD Candidate
}

Lecturer, "Aleksandër Moisiu" University, Business Faculty, Durrës, Albania

E-mail: bitilashosha@yahoo.com

\section{Doi:10.5901/jesr.2014.v4n6p546}

\begin{abstract}
In the face of economic and social conditions that Albania confronts nowadays, the development of the small business enterprises has a primary place as well as an important role, too. The business and enterprises literature shows that there are many factors determining the success and the growth of an enterprise. The profit is one of the most important factors for an enterprise to survive in a competitiveenvironment. Consequently, it is an important indicator of SMEs' performance. The profitability refers to the possibility of an enterprise to be financially successful. This can be assessed prior to entering the business or can be used to analyse an enterprise that currently is under operation.In this paper, profitability of SMEs is being measured through linear regression model. The data are collected through direct interviewsto businesses and real data are taken from the declaration forms of small business personal income tax payment (DFITP).
\end{abstract}

Keywords: SMEs, Profitability, Performance, indicator of SMEs performance; DFITP

\section{Scope of Paper}

This paper aims to study and analyse the correlation between profitability as per the perception of business owners in the field and profitability in $\%$ as per the real results declared at the Tax Office.

\section{Key Questions of Research}

Is there any relationship between profitability as perceived by business owners and profitability in \% (as measured by the ratio of gross profit / income from sales * 100 ) of SMEs?

\section{Profitability as a Performance Indicator}

\subsection{What is profitability?}

Profit has a great important for the survival of an enterprise in a competitive environment. It is an indicator of SMEs' performance. Gaining profit, or otherwise said being profitable/ lucrative, is the main goal of all undertakings. Measuring profitability current and past profitability is crucial. Predicting future profitability is also essential for a business venture survival.

Income and expenses are used to measure profitability. Income is the gross profit generated during the accounting period, as a result of the normal activities carried out by an undertaking. And incomes make the capital increase. ${ }^{1}$ Therefore, income is the money made by all the activities of a business. Having said this, it is important to stress that money coming from other activities, such as borrowing, do not create income. They are just a cash transaction between the business and the lender to generate cash for operating the business or buying assets.

Expenses ${ }^{2}$ are outflows (the decreases in economic profits) during the reporting period, resulting in the reduction of assets or increase in liabilities and reducing the capital.

Measuring profitability is the most important mean to measure the success of an undertaking.An undertaking that is not generating profit/ revenues, cannot survive. In the contrary, if an undertaking is much profitable, it has the capacity to pay back the owners in the form of return on investment made.

${ }^{1}$ National Accountability Standard p. 289

${ }^{2}$ National Accountability Standard p. 71 
Profitability can be defined either as an accounting or economic profit. Often, profitability is mistaken with the cash flow. Although they are closely linked to each other, they are two different things. Sometimes, people think that a profitable business has not problems with the cash flow. The Income Statement which is also referred as theperformance statement (thus, the success of an undertaking) reflects income and expenses, while the Cash Flow Statement reflects cash inflows and outflows. Thus, the Income Statement somehow shows the profitability of an undertaking, while the Cash Flow Statement shows liquidity thereof.

\subsection{Methodology of study}

The structure of groups of data provided by the questionnaires and the data provided by the declaration forms of small business personal income tax payment (DFITP), of Tirana General Directorate of Taxes, makes possible the use of statistical and mathematical methodologies of panel data to draw conclusions on the heterogeneous population of SMEs.

The data in this study are processed by statistical methods, mainly the linear and logistic methods applied by the SPSS software version 21. The interpretation of results is illustrated through the outputs in forms of tables and graphs. To analyse the data collected in this study, some linear and logistic regression models are used.

The analytical and conclusive methodology are used to test the consistency of hypotheses based on linear and logistic equations coefficients, derived as statistically significant explanatory factors,judging by the level of significance.

To do this a panel data taken from 300 questionnaires was used. The direct interview method was used to collect data from the SMEs owners in the city of Tirana. In addition 271 declaration forms were provided by Tirana General Directorate of Taxes.

\subsection{Setting up the statistical hypotheses}

In a research work, testing of statistical hypotheses is a very important procedure. On main objectives of the research work are based on such hypotheses. The hypothesis ${ }^{3}$ determines what requiresfurther research attention. Also, it provides a framework for organizing the conclusions resulting from the study.

The relationship between the dependent variable and the explanatory variables, in the terms of existence, will be referred as positive if the regression coefficients are different from 0 , with a predetermined significance level ( $p$-value $<0.05)$.

\section{Defining and Explaining the Variables}

The Linear Regression Model ${ }^{4}$, used in this research, will be explained below.

For a detailed study of the linear correlation of the dependent variable (Profitability) from the independent variable (Profitability in percentage) (or explanatory), the simple linear regression (with a single explanatory variable) is explained below.

The conclusions drawn for this correlation are interpreted by means of the linear regression outputs, according the SPSS version 21.

\subsection{Dependent variable (Profitability)}

One of the dependant variables, as important part of SMEs performance, used in this study is profitability. The data have been provided through direct interviews of business owners. The questionnaire contained 11 questions.

- Rate from 0 (not any) to 10 (fully), how much profitable do you think your business activity is j?

Y- PERC.RENTAB (indicator of profitability as per the business owners' perception).

\subsection{Independent variable}

Below, the Profitability in percentage (measured by ratio of gross profit / revenues from the sale) is taken as independent

3Hulley, S.; Cummings, S.; Browner, W, et al. Designing Clinical Research (3rd Ed.). Philadelphia, PA: Lippincott Williams \& Wilkins.

${ }_{4}^{4}$ Gujarati, D.N, 1995. 
variable. The data for the independent variable were obtained from the Tirana Tax Authorities.

The reason why this variable was chosen is because profitability in percentage, measured by this ratio, gives us factual data as provided by the declaration forms of income tax payment (DFITP).

$X$ - PERQ.RENTAB, Profitability in percentage (measures by the ratio of gross profit /income from sales *100).

To test the correlation RENTAB (profitability) of the dependant variable and X-Profitability in percentage (measured by the ratio of gross profit /income from sales) the following hypothesisis constructed:

\subsubsection{Hypothesis 1}

\section{$\mathrm{H}_{0}$ : Profitability in the perception of undertakingsis not affected by the profitability declared as for the DFITP. $\beta_{1}=0$}

$$
\begin{aligned}
& H_{1} \text { : Profitability in the perception of undertakingsis affected by the profitability declared as for the DFITP. } \\
& \beta_{1} \neq 0
\end{aligned}
$$

\section{Results of Econometric Model and Interpretation Thereof}

Table1.1. Summary of Model

\begin{tabular}{|c|c|c|c|c|}
\hline Model & $\mathbf{R}$ & $\mathbf{R}$ Square & Adjusted R Square & Std. Error of the Estimate \\
\hline 1 & $.423^{\mathrm{a}}$ & .179 & .176 & 1.87552 \\
\hline
\end{tabular}

Source: Author's calculations

Table 1.2. Coefficients of variables in equation

\begin{tabular}{|c|c|c|c|c|c|}
\hline \multirow{2}{*}{ Model } & \multicolumn{2}{|c|}{ Unstandardized Coefficients } & Standardized Coefficients & \multirow{2}{*}{$\mathrm{t}$} & \multirow{2}{*}{ Sig. } \\
\cline { 2 - 5 } & $\mathrm{B}$ & Std. Error & Beta & & \\
\hline (Constant) & 4.886 & .208 & & 23.482 & .000 \\
PERQ.RENTB & .057 & .007 & .423 & 7.651 & .000 \\
\hline
\end{tabular}

Source: Author's calculations

\begin{tabular}{|c|c|c|c|c|c|}
\hline Model & Sum of Squares & df & Mean Square & $\mathrm{F}$ & Sig. \\
\hline Regression & 205.929 & 1 & 205.929 & 58.543 & $.000^{\mathrm{b}}$ \\
\hline Residual & 946.226 & 269 & 3.518 & & \\
\hline Total & 1152.155 & 270 & & & \\
\hline
\end{tabular}

Table1.3. ANOVA of model

Source: Author's calculations

The econometric model generated by the processing of data collected, according to table 1.2 is given below:

\section{PERC.RENTAB $=4.886+.057$ PERQ.RENTAB +1.87552}

This model is statistically significant because the level of significance is within the limits, table 1.2 ( $p$-value $<0.05)$.

From the results of the statistical processing with the linear regression model in the SPSS software, we notice that $\beta_{1}=0.057$, table 1.2, i.e. $\beta_{1} \neq 0$; this means that hypothesis $\mathbf{H}_{0}$ does not stands and the alternative hypothesis $\mathbf{H}_{1}$ is accepted.

According to Hypothesis $\mathbf{H}_{1}$, this means that profitability in percentage is a real indicator having impact on the level of profitability as per the perceptions of SMEs owners. Such results are supported by the above equation.

Judging on the given linear regression equation, if we have an increase with 1 unit in the profitabilityin percentage, mathematically it brings an increase with 0.057 units of profitabilityas per the businesses perceptions. The standard error 
in estimation is $=1.87552$. The error scale in the perception of profitabilityis closely linked with the current situation of need for cash that the businesses may have.

The results of the linear regression model assessing profitability as perceived by businesses in the function of profit norm (as per the ratio of gross profit / income from sales * 100) indicates that there is a compatibility between the perceptions of business and the actual results provided by the declaration forms of income tax payment (DFITP).

The perceptions about profitability are evident by the responses given in the questionnaires. The questions were constructed according to the Likert scale:

- Rate from 0 (not any) to 10 (fully), how much profitable is your business activity?

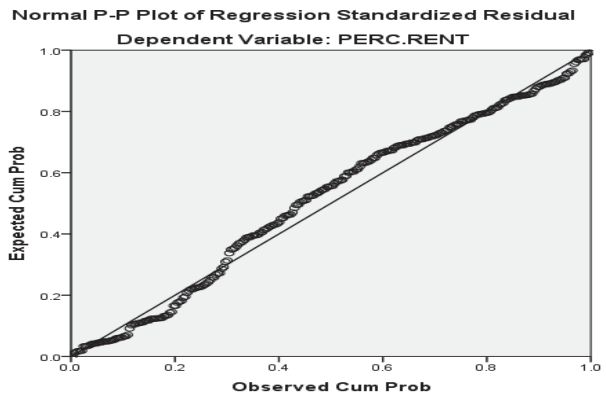

Graph 1.1. Linear Regression

Source: Author's calculations

According to Graph 1.1, we can draw the conclusion that the behaviour of factual data has a good approach towards the linear regression line, given in the above equation, with an average error $\varepsilon=1.87552$.

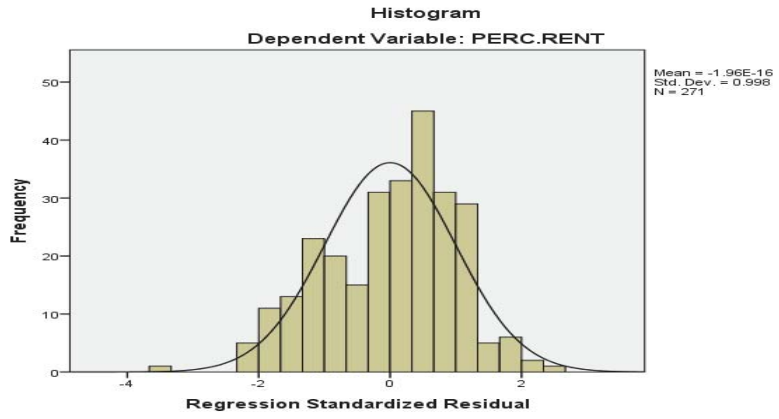

Graph 1.2 Histogram

Source: Author's calculations

The Histogram 1.2 reveals a normal approach of the processed values. It is noticed that the histogram has an almost normal behaviour.

\section{Conclusions}

According to the scope of this paper, the correlation between Profitability as per business owners' perception and Profitability in Percentage as per the factual results provided by the Declaration Forms of Income Tax Payment (DFITP) was the focal object in this study.

The results of the linear regression model, used to assess the Profitability as perceived by the businesses owners in the function of the profit ratio (as per the ratio of gross profit / income from sales * 100) indicate that there is a compliance between the business owners perceptions and the actual results provided by the Declaration Forms of Income Tax Payment (DFITP). 


\section{References}

A.K. Sharma, "Economic value added (EVA) versus conventional performance measures -empirical evidence from India", ASBBS Annual Conference: Las Vegas, February 2012, p. 804- 815.

Arellano, M. and Bond, S., 1991. "Some tests of specification for panel data: Monte Carlo evidence and an application to employment equations". Review of Economic Studies, 58 (2), 277-297.

Atkinson, J. and Meager, N. (1994). "Running to stand still: the small business in the labour market". In Employment, the small firm and the labour market (Ed.) J. Atkinson and D.J. Storey, London: Routledge.

Becchetti, L. and Trovato, G., 2002. "The determinants of growth for small and medium sized firms: the role of the availability of external finance". Small Business Economics,;

Bolton, J.E. (1971). "Report of the Committee of Enquiry on small firms". Bolton Report Cmnd. 4811. London: HMSO.

David J Storey, 1994, Understanding the Small Business Sector, London: Routledge,

David S. Evans, "The relationship between firm growth, size and age: estimates for 100 manufacturing industries". The Journal of Industrial Economics, 1987;

Davidsson, P. , Delmar, F. Wiklund, J. ,2006, "Entrepreneurship and Growth of firms";

Davidsson, P. and Wiklund, J., 2000. "Conceptual and empirical challenges in the study of firm growth" in: D. Sexton and H.

Elston, J. A., 2002. "An examination of the relationship between firm size, growth and liquidity in the Neuer Market". Discussion Paper, No 15. Frankfurt am Main: Economic Research Center, Deutsche Bundesbank.

Evans, D.S. and Leighton, L.S. (1990). "Small business formation by unemployed and employed workers", Small Business Economics, 2 (4): pp. 319-330.

Fazzari S. M., Hubbard, R. G. and Petersen, B. C., 1988. "Financing constraints and corporate investment". Brookings Papers of Economic Activity, (1), 141-195.

Freel, M. S. and Robson, P. J. A., 2004. "Small firm innovation, growth and performance". International Small Business Journal;

Garcýa-Teruel, P. J. and Martýnez-Solano, P., 2008. "On the determinants of SME cash holdings: evidence from Spain". Journal of Business Finance and Accounting, 35 (1) and (2), 127-149.

Hausman, J. A., 1978. "Specification tests in econometrics". Econometrica,

Heshmati, A. 2001. "On the growth of micro and small firms: evidence from Sweden". Small Business Economics, 17 (3), $213-228$.

Honjo, Y. and Harada, N., 2006. "SME policy, financial structure and firm growth: evidence from Japan". Small Business Economies, 27 (4), 289-300.

Kaplan, R. S. (1986), "Accounting lag - the obsolescence of cost accounting systems", California Management Review, Vol. 28 No. 2, pp. 174-199.

Kaplan, R. S. and D. P. Norton (1993). "Putting the balanced scorecard to work." Harvard Business Review September-October: 134147.

Kaplan, R. S. and D. P. Norton (2001). "The strategy-focused organization: how balanced scorecard companies thrive in the new business environment”, Boston, Mass.: Harvard Business School Press, 2001.

Kaplan, R.S. and Norton, D.P. (1992), "The balanced scorecard - measures that drive performance", Harvard Business Review, January-February,pp. 71-79.

Wiklund, J., Patzel, H. and Shepherd, D. A., 2009. "Building an integrative model of small business growth". Small Business Economics; 